\title{
Is Fair Market Competition Regulated under Syariah Law?
}

\author{
Safinaz Mohd Hussein
}

Associate Professor, Faculty of Law, Universiti Kebangsaan Malaysia

finaz@ukm.edu.my

\section{Ahmad Azam Mohd Shariff}

Associate Professor, Faculty of Law, Universiti Kebangsaan Malaysia

aazam@ukm.edu.my

Nazura Abdul Manap

Associate Professor, Faculty of Law, Universiti Kebangsaan Malaysia

nazura@ukm.edu.my

\section{Ramalinggam Rajamanickam}

Lecturer, Faculty of Law, Universiti Kebangsaan Malaysia

rama@ukm.edu.my

Mazliza Mohamad

Lecturer, Faculty of Law, Universiti Kebangsaan Malaysia

mazliza@ukm.edu.my

\section{Doi:10.5901/mjss.2014.v5n23p152}

Abstract

Competition law plays an extremely important role in today's business dealings. It promotes fairness in market competition by ensuring that every player gets to compete on common and equal grounds. In achieving this, competition law regulates and controls behavioural and structural conduct of market players through enforcement of anti-monopoly prohibitions, concerted conduct laws and merger laws. While development of modern man-made competition law has been brisk, it is interesting to simultaneously look into its development under syariah law. Does syariah principles promote fair market competition and if so, how refined are these principles? This article attempts to look into these issues. Being qualitative in nature, this legal study collects relevant materials, data and information on competition law in general. These are critically assessed and analyzed by way of library research. A critical analysis is also performed on all materials pertaining to syariah principles on competition. This study finds that syariah principles do protect market competition. However these principles are not as refined as the man-made principles, let alone codified. Ultimately, this study suggests that these syariah principles need to be further refined and codified in a single written legislation. Only then would syariah law be able to efficiently and effectively regulate and control market competition in any territorial jurisdiction.

Keywords: competition law; fair market competition; man-made competition law; syariah principles

\section{Introduction}

Competition law promotes and maintains competition in the market. It regulates the behavioural and structural conduct of players in the market through anti-monopoly prohibitions, concerted conduct laws and merger laws. This study meanwhile examines the question of whether or not syariah principles promote fair market competition. If they do, how refined are these principles? This study looks into these issues while simultaneously examines the development of man-made competition law for comparative purposes. 


\section{Research Materials and Methodologies}

The legal study conducted was indeed qualitative in nature. Being so, research methodologies of library research and critical analysis were used in analyzing relevant materials, data and information. This legal study has collected relevant materials, data and information on competition law in general. These were critically assessed and analyzed by way of library research. A critical analysis was also performed on all materials pertaining to syariah principles on competition.

\section{Modern Man-Made Competition Law and Its Objectives}

Around the world, the development of competition law has largely been geographical in nature. The existence of competition can be traced as early as the Roman Empire in Article 59(2) of the Constitution of Emperor Zeno of 483 AD. Earliest modern competition law has been stated to be the US Sherman Act of 1890. This was mentioned in Furse in Competition Law of the UK \& EC. In the US, the word 'anti-trust' is used with reference to competition. It developed from attempts (made in the US) to demolish 'trusts' or anti-competitive cartels or groups of the main manufacturers in particular industries that banded together to strengthen their hold on such industries and ensure that high prices and amenable terms and conditions were retained. The US legislation was aimed at breaking such trusts, hence the term 'anti-trust' utilized. This has been acknowledged by Singleton in Introduction To Competition Law.

Competition law in various jurisdictions has its own different objectives. It can be for the maintenance of effective competition as stated in the European Community (EC) competition rules (Roth Rose, 2001). As Furse pointed out, it could also be for the achievement of 'workable competition'. According to Encyclopedia of Competition Law, it could simultaneously be used to inhibit and break up concentrations of economic power. In Malaysia the importance and objective of competition is seen from the need to promote economic development by promoting and protecting the process of competition, thereby protecting the interests of consumers thereby protecting the interest of consumers and to provide for matters connected therewith. The process of competition encourages efficiency, innovation and entrepreneurship, which promotes competitive prices, improvement in the quality of products and services and wider choices for consumers. (Competition Act 2010)

In summary, objectives or purposes of competition law is generally for the promotion or preservation of competition in the market. This is expressed through the different usage of words and terms applied by various laws in different jurisdictions but they have similar objectives as mentioned above. The promotion and preservation of competition is done through the elimination of conduct, which would suppress competition. Behaviours such as collusion, cartel, price fixing, market allocation and abuse of market power are all suppressed and curbed.

Meanwhile, there is an ongoing argument that suggests that in certain jurisdiction the object of competition law might be for the protection of competition and in some it might be for the protection of competitors. This means that there is a difference between protecting competition and protecting competitors. There is also a proposition that competition law should protect competition and consumers and not protect competitors in the market.(Fox, 2003). Although it is true that ultimately the welfare of consumers is the object of competition law or the central importance of competition law, the result of cases has sometimes been inconsistent and contradicts this view.(Whish R, 2009). The different objectives and purposes enunciated by various competition law is a good articulation of the different concerns placed by different countries. The concerns placed by a particular legislation can be on consumer protection, redistribution, protection of the competitors or even a single market imperative.(Whish R, 2009). Therefore, it can be said that there is no one conclusive objective or one box fits all when it concerns the objectives of competition law.

The question of objective is very subjective and is very 'fluid.' The purposes and objectives of competition law correspond closely to the many benefits of competition law. The success of competition has been associated with lower prices, better products, wider choices and greater efficiency. (Whish R, 2009). De-monopolisation, liberalisation and privatisation result in lower prices, better products and greater efficiency because players need to compete with each other to remain in the market. Failure to be innovative and produce better product with lower prices for example, will cost the player its seat in the market. Therefore, the object of competition is simple which includes the breaking-up of concentration, the prevention of anti-competitive practices or the prevention of abuse of market power. The benefits of competition are clear. With lower prices and better products, for example, the market works better to the advantage of consumers.

\section{Malaysian Competition Law}

The process of privatisation in Malaysia deregulates and opens up state monopolies to greater competition. Privatisation 
transfers assets from the public sector to the private sector reducing the role of the government. In the absence of a national competition law or policy, sectoral approach to competition regulation was adopted. (Khairiah, 2008). Examples of sectoral regulation to regulate competition are Price Control Act 1946, the Trade Description Act 1972, the HirePurchase Act 1967, the Control of Supplies Act 1961, the Weight and Measures Act 1972, the Consumer Protection Act 1999 and the Direct Sales Act 1993. These statutes regulate competition by protecting the rights of the consumers and preventing various acts, which are considered illegal on the part of the provider or traders. These laws address specific issues for example the control of price and the control of supplies. It does not address competition issues such as market structures and power like anti-competitive practices and the abuse of dominant position. However, these sectoral laws could not be equated to sector-specific competition laws as it only addresses specific issues like the Price Control Act 1946 tackles the issue of control of price whereas sector-specific laws would not only cover pricing issues but of wider scope which includes anti-competitive behaviour and abuse of market power. Currently, apart from the Malaysian general competition i.e. the Competition Act 2010, only two sectors expressly addresses competition in Malaysia i.e. the communications and multimedia and the energy sectors through the Communications and Multimedia Act 1998 and the Energy Commission Act 2001 respectively.

In 2010 the Malaysian Parliament finally passed the Competition Act 2010. The Competition Act 2010 is divided into six parts. However, only Part II deals with anti-competitive practices. The other parts contain provisions on procedures of the Competition Commission (also known as the Malaysian Competition Commission or MyCC established by the Competition Commission Act 2010), provisions on the competition appeal tribunal and general and preliminary provisions. Part II of the Competition Act 2010 contains four chapters. Sections 4 to 9 are on anti-competitive agreement, section 10 is on abuse of dominant position, sections 11 and 12 deal with market review while section 13 is on exclusion. Generally, most competition law deals with three general aspects of regulation, i.e. prohibitions on anticompetitive conduct, abuse of dominant position and rules on mergers and acquisitions. According to Martyn Taylor, this approach is similar or common to most competition law.(Martyn, 2006). He highlighted three general elements of competition law exhibited by APEC nations are merger laws, anti-monopoly laws and anti-competitive practices laws. Two of these elements are seen adopted by the Competition Act 2010. The Competition Act 2010 addresses both anticompetitive conduct and abuse of dominant position in Chapters 1 and 2 of Part II. It does not however contain provisions on mergers and acquisition, taking into account the views of various parties like the Securities Commission and the Bank Negara Malaysia that they are already addressed under section 33A of the Securities Commission Act 1993 and the Malaysian Code on Take-overs and Mergers 1998.(Refer to Parliamentary Debate, 8 April 2010). This argument can be criticized especially when both instruments lack concrete competition provisions.

The Competition Act 2010 contains two main prohibitions i.e. prohibition on anti-competitive agreement (Section 4) and the prohibition on the abuse of dominant position (Section 10). Section 4 of the Competition Act 2010 prohibits, "a vertical or horizontal agreement between enterprises ... which has the object or effect of significantly preventing, restricting or distorting competition in any market ..." Subsection (2) of the same section further lists a number of horizontal agreements which are per se prohibited. They are:

(a) price fixing;

(b) sharing of market or sources of supply;

(c) limit or control of production, market outlets or access, technical or technological development, investment;

(d) bid rigging.

The second general prohibition addresses the abuse of dominant position. Section 10(1) of the Competition Act 2010 provides that "an enterprise is prohibited from engaging, whether independently or collectively, in any conduct which amounts to an abuse of a dominant position in any market for goods..." and an abuse of a dominant position may include-

(a) the imposition of unfair purchase or selling price whether directly or indirectly or unfair trading condition;

(b) the act of limiting or controlling the production, market outlets or market access, technical or technological development, or investment;

(c) refusing to supply;

(d) the application of dissimilar conditions to equivalent transactions with trading partners;

(e) tying;

(f) predatory behaviours;

(g) buying up scarce supply of goods or resources without a reasonable commercial justification.(look up for Section 10 (2) as well).

Section 10 (4) of the Act also provides that the market share of an enterprise is not by itself an indication of dominance. The rest of the provisions under Part II of the Competition Act 2010 contain provisions market review to study 
the structure of the market and conduct of the players and exclusion provisions where activities or conducts listed in the Second Schedule will be excluded from provisions of Part II (Anti-competitive practices). In other words, the Competition Act 2010 encompasses lists of anti-competitive conducts, which are prohibited (Martyn, 2006), approaches to counter anti-competitive conduct and list of exemptions and authorisation. Two types of approaches will be adopted to counter anti-competitive conduct, preventive approach and the remedial approach. These approaches will be structural and behavioural in nature. These approaches are similar to those in other jurisdictions and drawn attention by the international bodies like the UNCTAD, who mentioned that there is no unique model to follow however, the Competition Act 2010 contains characteristics generally similar to those proposed by the model law.

\section{Market Competition: The Syariah View}

This study finds that syariah principles do promote market competition. For instance, price fixing and monopoly have been prohibited as early as the time of the Prophet Muhammad (S.A.W.). This goes to show the similarity between modern competition law concepts and syariah principles on market competition.

Syariah principles on competition were not founded on the idea of absolute right of private ownership and engagement in private enterprise. Rather they were founded on transformation of the concept of ownership into that of trusteeship. According to these principles individual freedom is subject to social regulation and control. As such, the right of ownership is given to man as a trustee to do good.

There are various verses in the Quran which promote justice and fairness. For example in Al Maidah verse 8, the translation provides "O ye who believe! Stand out firmly For Allah, as witnesses To fair dealing, and let you not The hatred of others To make you swerve To wrong and depart from Justice. Be just: that is Next to Piety: and fear Allah. For Allah is well-acquainted With all that ye do." (A Yusuf, 1989).

In general, syariah principles do promote free market and in normal market condition, the forces of demand and supply control prices. Ibn Taimiyah said, "Rise and fall in prices is not always due to an injustice (zulm) by certain individual. Sometimes the reason for it is deficiency in production or decline in import of the goods in demand. Thus if desire for the goods increase, its price rises. On the other hand, if availability of the goods increase and the desire for it decrease, the price comes down. This scarcity or abundance may not be caused by the action of any individual, it may be due to a cause not involving any injustice, or sometimes, it may have a cause that does not involve injustice. It is Almighty God who creates desires in the hearts of people..." (A Azim, 1988; Taimiyah, 1963). Therefore, Islam forbids any attempts to influence prices through creating artificial element such as shortage of supply. Dr Mohammed Obaidullah expresses his views in Ethics and Efficiency in Islamic Stock Market: Islamisation and Stock Market Effciency, as viewed at http://vlib.unitarklijl.edu.my/htm/islamicethic.htm, and points out that such attempts to influence prices in markey is actually known as ihtikar.

The issue of competition in Islam is discussed in the principle of ihtikar. Ihtikar, principally, is defined as "...hoarding up grain with the object of raising the price..." (Ichtiar,1996). It comes from the combination of the words hakara which refers to az-zulm or injustice. It refers to the ability to hoard goods (trade) until the price is raised. The Maliki school states that the prohibition on Ihtikar is not limited to goods but to services so long as it is something that is needed by the society. (Ichtiar, 1996). In other words, The prohibition of intikar is authenticated from a few verses in the Quran namely al Naml verse 90, al Nisa verse 58 and al Hadid verse 25. There were even traditions or hadith of the Prohphet Muhammad putting great emphasis on justice. In Hud verse 85 it was stated where the translation means, "And 0 my people! Give Just measure and weight, Nor withhold from the people The things that they are due: Commit not evil in the land With intent to do mischief." (A Yusuf, 1989).

Syariah principle explicitly forbids ihtikar. This is prescribed in the tradition of the prophet which says:"... whoever withholds cereals that they may become scarce and dear, is a sinner..." This tradition emphasizes the fact that ihtikar or the act of monopolizing supply (hoarding) to increase price is forbidden under syariah law. It means that in terms of competition, syariah principle ensures just and fair market price in maintaining justice in dealings amongst members of the society. That is why such act of monopolizing supply to increase market price with view of maximizing profit is prohibited and against public interest. (A Mahyuddin, 1975).

Ihtikar also includes any kind of effort which may influence the price of the goods or services through monopolizing the production of goods or via immoral or unethical competition. Therefore, essentially, the act of monopoly is forbidden particularly, when it affects the interest of the consumers or public at large. Syariah principle regards such act as against public interest and whenever individual rights clashes with public interest, the latter prevails. Hence, syariah law recognizes free market and prohibits anti-competitive acts of monopolizing and price fixing. These are all common values shared between syariah as well as modern man-made competition law. Both are clearly against monopoly which clearly 
discourage competition. Clearly both syariah and man-made principles disapprove monopoly which can lead to an abused dominant position or market power. Both principles also disapprove price fixing being usually a per se prohibition under competition law. This could be seem in Article 81 and 82 of the EC Treaty and Section 45 and 46 of the Australian Trade Practices Act 1974.

Syariah law also recognizes the need for an institution to regulate competition. Al-Hisba is one such institution being developed to help regulate the society and economy. Al-Hisba maintains public law and order and supervises against dishonesty and malpractice amongst the behaviour of the buyers and sellers in the market. The responsibilities of Hisba includes checking for bad workmanship or faulty measures or discrepancy in quality. It also ensures that there is no arbitrary manipulation of the market, by resort to hoarding, under-utility, over-charging, obstructing supplies, etc. In other words, al Hisba is responsible for the protection of the suq (market) and its existence is to foresee injustice in the market.(Taimiyah, 1985).

Even though syariah law favours free market, intervention in the regulation of prices and market conditions is only allowed in cases of market failure. In such cases, syariah principle lays a duty on public authorities to act in the interest of the people. Therefore, if for example, prices charged by a dominant player are excessive or unfair, or fixed through anticompetitive agreements or other forms of collusion between the market players, the state should intervene to fix or regulate the price. This duty is based on the concept of maximizing consumer welfare towards eradicating the suffering of effected people. Imam Ibn Taimiyyah commented that in cases where price in the market 'is not fixed at a reasonable level to fulfil the need of the great public by the operation of normal principles of marketing, then the price should be fixed for the welfare of the people with justice neither more or less.'(Maher, 2007).

The similarities between both syariah as well as modern man-made principles on market competition are evident in terms of anti competitive conducts, anti-monopoly laws and mergers. Truly syariah law promotes free market and monopoly and price fixing are prohibited as these may cause injustice to the people.

\section{Problems and Findings}

This legal and qualitative study has collected and examined relevant materials, data and information on competition law. A critical analysis was also performed on all materials pertaining to syariah principles on competition. Materials on modern man-made competition law were also critically assessed and analyzed. Principle wise, there are indeed syariah principles which regulate fair market competition. In fact there are similarities in principles between syariah and manmade principles on competition. Hence, this study finds that syariah principles do protect market competition. However these principles are not as refined as the man-made ones and they are off course uncodified. The need to further refine and codify syariah principles on market competition are based on the following arguments:

- Refinement and codification of syariah principles are based on maslahah or public interest

Any effort of refining and codifying all relevant syariah principles on competition are based on public interest. This is because such move will advocate efficiency and improve legal application and enforcement. This would definitely ensure better and fairer market competition among players and ultimately protects the public. The Prophet SAW, in one of his traditions, once said that Islam is not chaotic and will never create chaos to others. (Muhammad, 1952; A Sudirman, 2004). Hence, it is clear that such refinement and codification, if to be made, is aimed at improving the life of the public and protecting them from problems and chaos. Ibn Qayyim once said that the syariah principles will always be based on maturity, practicality and public interest. It is also based on justice and prosperity. (Ibn Qayyim, 1994).

- Refinement and codification of syariah principles are done on the basis of hajiyat or necessity

Efforts of refining and codifying all relevant syariah principles on competition, if to be done, are based on necessity. Hājiyāt or necessity means that efforts and changes must be made in improving market competition and providing a fairer and more efficient competitive environment. Such move is considered a necessity and if not made, the public market would face problems and hiccups which, in turn, could potentially accelerate to bigger future problems and chaos if left unattended. Hence, any move to further refine and codify syariah principles on market competition which would ensure efficiency and improvement on legal application and enforcement are all based on the concept of hājiyāt or necessity as upheld by muslim scholars.(Hashim, 1999; Qardhawi, 1996).

\section{Concluding Remarks}

This study observes that syariah law do promote fair market competition. Indeed there are a lot of similarities in principles between syariah and man-made principles on competition. However these syariah principles could further be refined so as to ensure more effective and efficient enforcement. This study ultimately suggests that these syariah principles need to 
be codified in a single written legislation. The Malaysian legislation on competition could serve as a good guideline and example on how such principles should be codified. Only then could market competition be effectively regulated and controlled.

\section{References}

Abdul Azim Islahi. (1988). Economic Concepts of Ibn Taimiyah. Leicester UK: The Islamic Foundation.

Abdul Yusuf Ali. (1989). Translation of The Holy Quran.

Ahmad Mahyuddin Ahmad Hassan. 1975. Amal Sharikat al-istithmar al-Islamiyyah fi al-suq al-Alamiyyah. Bahrain: Bank al-Barakah al Islami lil Istithmar.

Ahmad Sudirman Abbas. (2004). Sejarah Qawa'id Fiqhiyyah. Jakarta: Pedoman IImu Jaya dan Anglo Media.

Australian Trade Practices Act 1974 - Section 45 and 46

EC Treaty - Article 81 and 82

Eighth Malaysia Plan - Paragraph 16.32; Taklimat Mengenai Draf Dasar Amalan Perdagangan Adil (DAPA) Kementerian Perdagangan Dalam Negeri Dan Ehwal Pengguna Kepada Wakil-Wakil Kerajaan Negeri (25 Julai 2003), Hotel Sheraton Imperial, Kuala Lumpur.

Encyclopedia of Religion <http://www.world-religion.org/articles/ili 1645.php>Encyclopedia of Competition Law, "Competition Law" para $1-001$.

Ensiklopedia Hukum Islam. (1996). Jakarta: Penerbit PT Ichtiar Baru Van Hoeve.

Fox, EM, "We Protect Competition, You Protect Competitors" (2003) 26 World Competition 2.

Ichtiar Baru. (1996). Ensiklopedia Hukum Islam. Jakarta: Penerbit PT Van Hoeve.

Ibn Qayyim. (1994). l'lam al Muwaqqi'ien. Vol. 2. Beirut: Darul Kutub Ilmiyyah.

Ibn Qayyim. (1967). I'lam al Muwaqqi'ien. Mesir: Maktabah al Kulliyyah al Azhariyyah.

Ibn Taimiyah. (1963). Majmu Fatawa Shaikh al-Islam. Vol. 8. Riyad: Matabi al-Riyad.

Ibn Taimiyah. (1985). Public Duties in Islam The Institution of the Hisba, (Translated by Muhtar Holland). Leicester UK: The Islamic Foundation.

Khairiah Salwa Mokhtar. (2008). Privatisation Malaysia Airlines, Bangi: Penerbit UKM.

Maher M. Dabbah. (2007). Competition Law and Policy in the Middle East. Cambridge.

Martyn Taylor. (2006). International Competition Law: A New Dimension In The WTO. Cambridge, Cambridge University Press.

Mohammad Hashim Kamali. (1999). Principles of Islamic Jurisprudence. Selangor: IImiah Publishers.

Muhammad bin Zaid. (1952). Sunan Ibn Majah. Kaherah: Mustafa al Halabi.

Roth P, Rose, V, (Editors). 2001. Bellamy \& Child European Community Law of Competition. Sixth Edition. Sweet \& Maxwell.

Whish, R. (2003). Competition Law. Fifth Edition. LexisNexis Butterworths.

Whish, R. (2009). Competition Law. Sixth Edition. Oxford University Press.

Yusuf Al Qardhawi. (1996). Memahami Keutamaan Berasaskan Al Quran Dan Al Sunnah. Selangor: ABIM. 